\title{
IMPACT OF EMOTIONS \& MOODS OF EMPLOYEES ON ORGANIZATION PERFORMANCE
}

\section{Muhammad SARMAD*,}

University of Agriculture, Faisalabad Sub-Campus Burewala-Vehari, Pakistan

Allena RAZZAQ,

University of Agriculture, Faisalabad Sub-Campus Burewala-Vehari, Pakistan

\section{Ali RAZA,}

University of Agriculture, Faisalabad Sub-Campus Burewala-Vehari, Pakistan

Khadija YOUNAS,

University of Agriculture, Faisalabad Sub-Campus Burewala-Vehari, Pakistan

\section{Zara KHAN}

University of Agriculture, Faisalabad Sub-Campus Burewala-Vehari, Pakistan

(C) The Author(s) 2020

\section{ABSTRACT}

The purpose of this study was to inspect the relationship between emotions and moods of employees on organizational performance. After the data was collected, SPSS 2.0 version were used to measure the data. Correctness of data entry was checked. Descriptive and inferential statistical techniques were used for data analysis. Pearson's correlation and multiple regression analysis were used to assess both relationships and effects as per the hypotheses of the study. The data which was collected through survey. About 130 Questionnaire were distributed in Burewala area, from which 118 questionnaire were received back. The limitations connected with analysis area unit acknowledged. There must to be more study on this subject to know the connection between these factors and their impact on one another.

This analysis was on little scale, the sample size was also little. So, the study should conducted on large scale area along with larger sample size. This study is very helpful to see the effect of employee's emotions and mood on organization performance. Policies makers should developed the strategies to maintain the employee's emotions. The originality in this research was the specific area. This research applied in Burewala area. Because in this area the research with these variable are not applied before.

\section{ARTICLE HISTORY}

Received: 29/05/2020

Accepted: 21/10/2020

Published online:30/10/2020

\section{KEYWORDS}

Employees Emotions, Employees Mood, Organization Performance, Organizational Behavior, research

*Corresponding Author 


\section{Introduction}

This study gives us the knowledge of how the moods and emotions are effect on work performance on the employees in an organization. As we know about the study of organization behavior if the moods of the employees are good or they satisfy for the job and manager keep the emotions of the employees, they are satisfy for their job so they give better work performance in this we produce more product and gain maximum profit. Organizations have realized that employee emotions and moods are general in the workplace. The emotions and moods are not only a deep-seated part of work life but have an important role to play in one's job performance and satisfaction. An employee's emotions and overall temperament have a significant impact on his job performance, decision making skills, team spirit, leadership, and turnover and job satisfaction. It is believed that employees bring their feelings of anger, fear, love and respect with them when they come to work.

Emotions and moods of workers matter as a result of them drive employee's performance and have influence on job satisfaction. Moods or emotions at work place, generally, fall into positive and negative emotions. Positive moods or emotions are those feelings of a personal that favorable to the achievement of structure goals whereas negative moods or emotions are those who appeared to be harmful for the organization and structure goal. Positive moods or emotions increase ability, encourage serving to behavior and cooperation and cut back aggression each against the organization and against individuals. Analysis suggests that positive individuals have higher psychological feature talents and have a tendency to try and do higher within the geographical point and with accuracy. Emotions and moods directly effect on organization behavior, thus one needs to manage emotions and moods whereas at work. Some jobs merely cannot be done, if emotions and moods don't seem to be proscribed 1st. Imagine however workers whose job tasks needs specific emotions (ability to manage their emotions and moods), just like the front officer or client care executives.

Emotion and mood of employees have a great effect on achievement and the organization performances, Labor Productivity, Quality of Products / Works / Services offered to customers. They also effect the production costs, the organization's image, and the relationship with customers, Suppliers, Authorities, Public institutions and the society as a whole. For example; if the conflict arises among the employees or the manager are biased between them for someone so it 
cause to hurt the emotions of the other employee. May be, he left the job or he does not doing the job with efficiency. So it effect on organizational performance.

All moods and emotions have effect on judgment, perception, and physical and emotional well-being. The choice creating effects of any practically unhealthy mood will delay a personality's job performance and result in poor selections that have an effect on the corporate. In distinction, a positive mood will enhance ability and downside determination. However, positive moods can even produce false optimism and negatively influence higher cognitive process.

The mood varies from person to person. It is variable at the same person and it changes from one department to department within the organization. What's more, mood has a clear impact on person performance - both how much work employees do and how well they do it.

\section{Literature review}

Emotions and moods have an important role in work performance. (Finucane et al) suggest that emotions act as an exploratory. That is, emotions provide an accessible summary of experience, perceptions and memories. (al, 2000)

Akhtar et al, (2017) said that Use of emotions is related to individual's ability to use their emotions by directing them toward productive activities and personal performance. Experience indications that employee's emotions and mood contributes to explaining performance of employee's. Furthermore, employee's emotions and mood improves outcomes on various measures relevant to the realms of work and career building, including transformational leadership, conflict resolution, political skill, job success and performance at job (et, 2017)

Wong (2017) said that emotionally intelligent have strong control on their emotions and therefore they have more efficient and effective interaction with their work environment and with co-workers. The relation between emotional intelligence and performance has been suggested that there is positive relationship between emotional intelligence and work/ performance when they worked in organization. Regulation of emotions is related to individual's or person's ability to control one's own emotions, so that they will be enable more rapid recovery from psychological suffering. (Wong, 2017)

Brieft and George (2006) tells in his research Organizations have realized that employee emotions and moods are unescapable in the workplace. The emotions and moods are not only a deep-seated part of work life but have an important role 
to play in one's work performance and employee's satisfaction. An employee's emotions and mood have an important effect on his work performance, decision making skills, team spirit, leadership, and turnover and job satisfaction. It is believed that employees bring their feelings of anger, fear, love and respect with them when they come to work.Emotions and moods of employees matter because they drive employee's performance and have influence on job satisfaction. (Brief, 2006)

In the work environment, investigators found relations between mood and performance, organizational, pro-social behavior at work, employee withdrawal behavior, and creativity in the workplace. Though the possibility of mood's research was enlarged, one needs to fulfil with specific work characteristics where moods are stronger in attention, especially in customer service organizations, where more organizational performers are involved. Groth suggest in his study that when a customer interacts with an organization during service delivery, their exchange can similarly be considered a social exchange', consumers' mood can and should not be ignored as emotional infection. (Groth, 2005)

Emotions and moods are an important part of human lives, especially work lives. But how do emotions and moods effect on work performance and work satisfaction? A model called Affective Events Theory (AET) has increased understanding of the relations between emotions and work performance. AET shows that employees respond emotionally to event that occurs to them at work and that this response effects on employee's work performance and work satisfaction. Affective Events Theory (AET) is a model developed by organizational psychologists Howard and Russell (1998) to explain how emotions and moods effect on work performance and work satisfaction (Phua:Thomsan, 2012).

The model explains the relations between employees' internal effects like, cognitions, emotions, mental states and mood and their reactions to events that occur in their work environment that affect their work performance, organizational commitment, and work satisfaction. The theory suggests that emotional work behaviors are explained by employee mood and emotions, while cognitive-based behaviors are the best predictors of work performance \& satisfaction. (Wegge:Dick:Fisher, 2006) The theory proposes that positive-inducing as well as negative inducing emotional incidents at work are distinguishable and have a significant psychological impact upon workers' job satisfaction. This results in lasting internal and external affective reactions exhibited through job performance, job satisfaction, and organizational commitment. (Al, 2006) 
(Izard, 1991) Says that emotions of constant sign (positive or negative) supported similarity that unit activated at constant time. As associate degree example, a positive feeling (joy), activates various emotions of constant kind (satisfaction, wellbeing, optimism) and at close to psychological feature triggers tend purpose. A negative feeling like anger, emotions activate constant sign, disgust, contempt and have an inclination to avoid the destruction of its purpose. If the models of separate emotions - inside the course of emotional experience - and a reasonable interpretation, then the response sequences unit redoubled by psychological feature assessment, either utterly or negatively

Emotions have a deep effect on almost everything we do in the workplace or an organization. The field of Organization Behavior expected that a person's thoughts and actions are directed mainly by conscious cognitive. Yet, groundbreaking neuroscience discoveries have revealed that our perceptions, decisions, and behavior are effected by both thought and emotion, and that the latter often has the greater effect. By ignoring emotionality, many theories have ignored a large piece of the puzzle about human behavior in the organization. (Smith, 1993)

Goleman (2005) said that emotion and mood is serious to high performance, a person who knows how to stay motivated under stress, motivate others, manage complex interpersonal relationships, his/her others and build teams who are recognized specialists on a product or service are likely to get will get better results. In the words of Jordan and Peter (2009). Emotions and mood a multi-dimensional concept that links emotion and cognition to improve human communications. It has been related to improved organizational performance behavior. (Naseer:Zainab:Saeed-ul-Hassan, 2011)

\section{Research Objectives}

$>$ To study the relationship between emotions and mood on work performance.

$>$ To recognize the scopes of emotion \& mood and effect on the organizational performance.

$>$ To measure the level of emotions and mood of the employees and its effect on their work performance. 


\subsection{Significance of our study}

In this study we are going to discuss the importance employee's emotions and moods. How employees emotion and moods effect on organizational performance. Emotions and mood are the internal feelings of employees. An employee who works in an organization with deep of heart. While working which event or thing are occur that effect on employees emotion and what steps will be to overcome the negative emotion which create hurdle on performance

\subsection{Theoretical framework}

Work/Organizational performance depends on employee's emotions \& moods in the workplace.

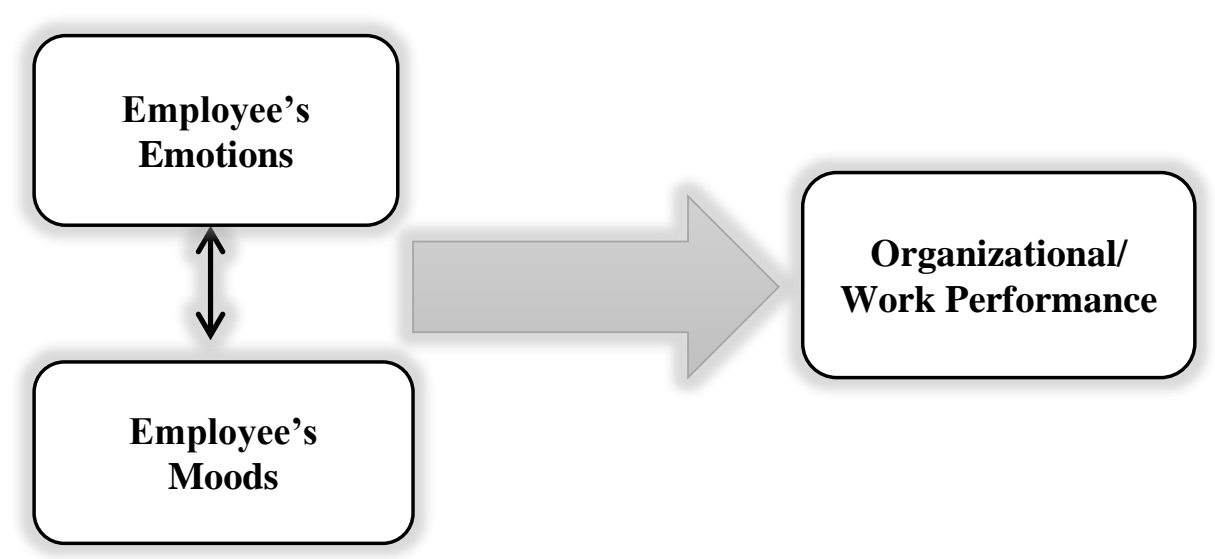

\section{Figure.1.}

Organizational performance depends on employee's emotions and mood. If employees have mood to work and have positive emotions with their workplace then there will be defiantly increase in employees work performance. If they have no positive emotions and mood so there will be decrease in work performance. So, Emotions and mood are independent variable and organizational performance are dependent variable. 


\subsection{Hypothesis}

Ho: There is positive relations between employee's emotions \& mood and organizational performance

H1: There is negative relations between employee's emotions \& mood and organizational performance

\section{Research Methods \\ 4.1.Population Sample and Data Collection}

The study of population about different types of organization like, School, Colleges, Malls. The data was collected from Area of Burewala/Vehari. The reason of choosing these organizations that how organizations performance effect by employees emotions and mood. How they used their emotions in positive sense and how they overcome employee's negative emotions. A sample of 120 people was considers for analysis and received $85 \%$ questioner are received back.

\subsection{Instrument and Measurement}

There are number of typologies, categories and instrument to measure the emotions and mood of employees on work performance. To measure the dimensions of emotions of employee's survey questioner method was adopted. The survey of questioner included the individual demographic of responders like age $\&$ gender etc.

\subsection{Data Analysis}

The research was directed in order to measure that in which sense employees used their emotions. We use SPSS 2.0 version for measuring the data.

\section{Findings}

Table .1.

\begin{tabular}{|r|c|c|c|c|}
\hline & $\begin{array}{c}\text { Frequenc } \\
\mathbf{y}\end{array}$ & Percent & $\begin{array}{c}\text { Valid } \\
\text { Percent }\end{array}$ & $\begin{array}{c}\text { Cumulative } \\
\text { Percent }\end{array}$ \\
\hline Male & 60 & 50.8 & 50.8 & 50.8 \\
Valid Female & 58 & 49.2 & 49.2 & 100.0 \\
Total & 118 & 100.0 & 100.0 & \\
\hline
\end{tabular}




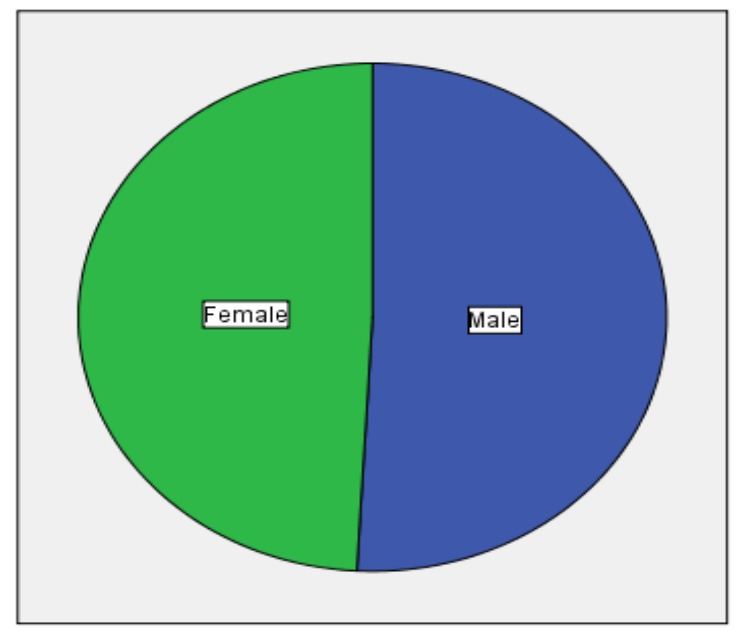

Figure .2.

The Table .1 shows that $51 \%$ of sample are male and $49 \%$ are female.

Table .2.

\begin{tabular}{|} 
Age \\
\begin{tabular}{|r|l|l|l|l|}
\hline & Frequency & Percent & $\begin{array}{l}\text { Valid } \\
\text { Percent }\end{array}$ & $\begin{array}{l}\text { Cumulative } \\
\text { Percent }\end{array}$ \\
\hline $20-25$ & 17 & 14.4 & 14.4 & 14.4 \\
$26-30$ & 59 & 50.0 & 50.0 & 64.4 \\
Valid $31-35$ & 22 & 18.6 & 18.6 & 83.1 \\
$36-40$ & 20 & 16.9 & 16.9 & 100.0 \\
Total & 118 & 100.0 & 100.0 & \\
\hline
\end{tabular}
\end{tabular}




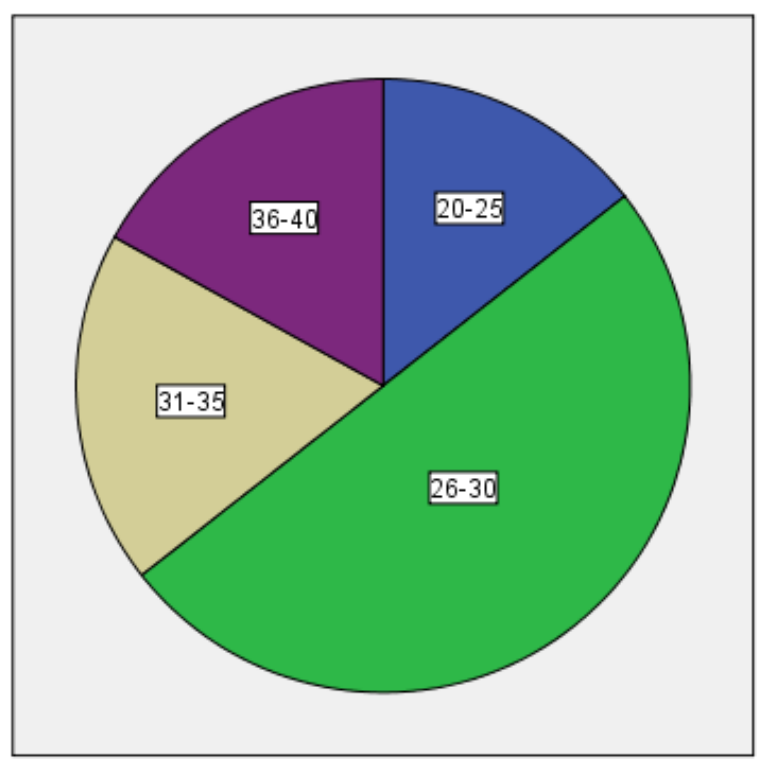

Figure .3.

This table shows that $14.4 \%$ of sample are falls between the age group $20-25,50 \%$ are falls between $26-30,16.6 \%$ are falls $31-35$, and $16.9 \%$ are falls in $36-40$.

\section{Table.3.}

\begin{tabular}{|c|c|c|c|c|c|}
\hline \multicolumn{6}{|c|}{ Job Nature } \\
\hline & & Frequency & Percent & $\begin{array}{l}\text { Valid } \\
\text { Percent }\end{array}$ & $\begin{array}{l}\text { Cumulative } \\
\text { Percent }\end{array}$ \\
\hline \multirow{5}{*}{ Valid } & Teaching & 8 & 6.8 & 6.8 & 6.8 \\
\hline & Operational & 63 & 53.4 & 53.4 & 60.2 \\
\hline & Manager & 24 & 20.3 & 20.3 & 80.5 \\
\hline & Other & 23 & 19.5 & 19.5 & 100.0 \\
\hline & Total & 118 & 100.0 & 100.0 & \\
\hline
\end{tabular}




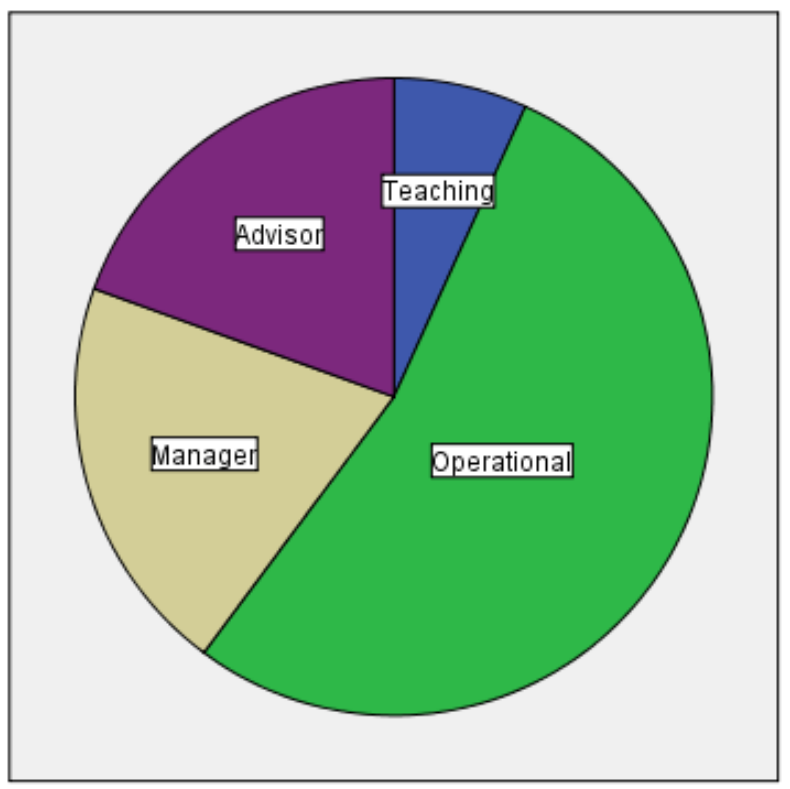

Figure. 4.

The table shows that $6.8 \%$ people are Teachers, $53.4 \%$ are performing operational jobs, $20 \%$ are related to management, $19.5 \%$ are performing different kind of duties.

\section{Table .4.}

Experience for current job?

\begin{tabular}{|ll|l|l|l|l|}
\hline & Frequency & Percent & $\begin{array}{l}\text { Valid } \\
\text { Percent }\end{array}$ & $\begin{array}{l}\text { Cumulative } \\
\text { Percent }\end{array}$ \\
\hline \multirow{6}{*}{ Valid } & 0-1 year & 12 & 10.2 & 10.2 & 10.2 \\
& 1-3 years & 11 & 9.3 & 9.3 & 19.5 \\
& $3-5$ years & 7 & 5.9 & 5.9 & 25.4 \\
& $5-10$ years & 51 & 43.2 & 43.2 & 68.6 \\
& $10+$ & 37 & 31.4 & 31.4 & 100.0 \\
& Total & 118 & 100.0 & 100.0 & \\
\hline
\end{tabular}




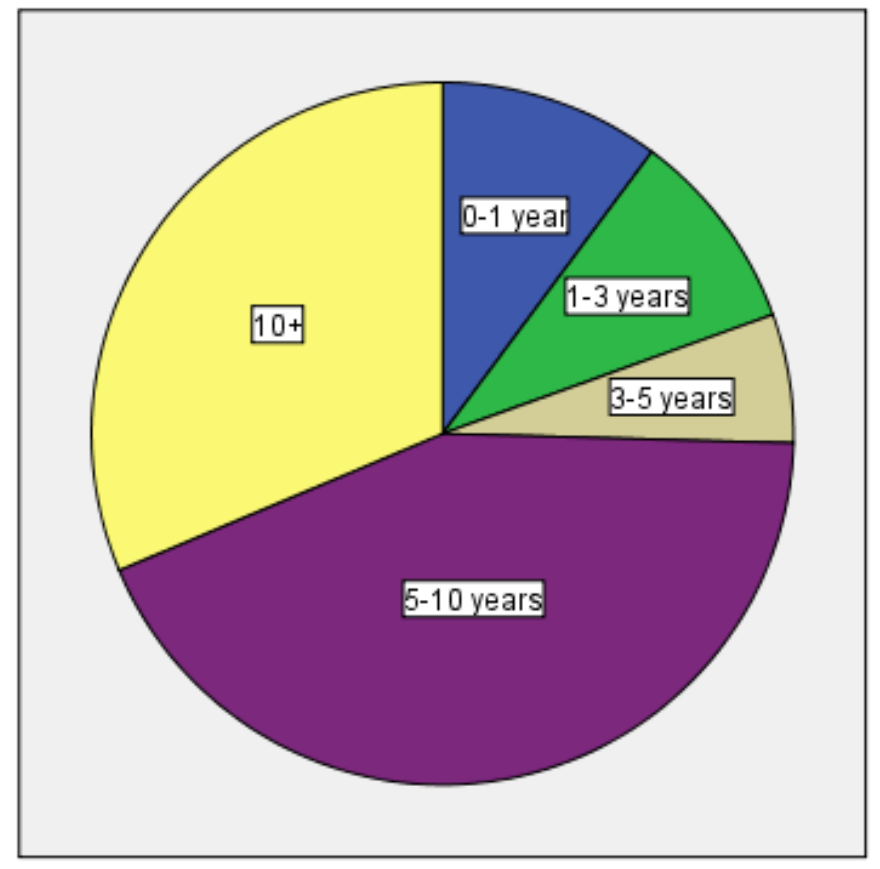

Figure .5.

The table shows that $10 \%$ have 1 year job experience, $9.3 \%$ have between $1-3$ years job experience, 5.9\% have between 3-5 years job experience, $43.2 \%$ have between 5-10 years job experience, and $31.4 \%$ have more than 10 years job experience.

\section{Table.5.}

Are you satisfy with your current job
\begin{tabular}{|l|l|l|l|l|}
\hline & Frequency & Percent & $\begin{array}{l}\text { Valid } \\
\text { Percent }\end{array}$ & $\begin{array}{l}\text { Cumulative } \\
\text { Percent }\end{array}$ \\
\hline $\begin{array}{l}\text { Strongly Disagree } \\
\text { Disagree }\end{array}$ & 8 & 6.8 & 6.8 & 6.8 \\
Somewhats Agree & 18 & 5.9 & 5.9 & 12.7 \\
Valid Some Disagree & 15.3 & 15.3 & 28.0 \\
Agree & 44 & 37.3 & 37.3 & 65.3 \\
Strongly Agree & 41 & 34.7 & 34.7 & 100.0 \\
Total & 118 & 100.0 & 100.0 & \\
\hline
\end{tabular}




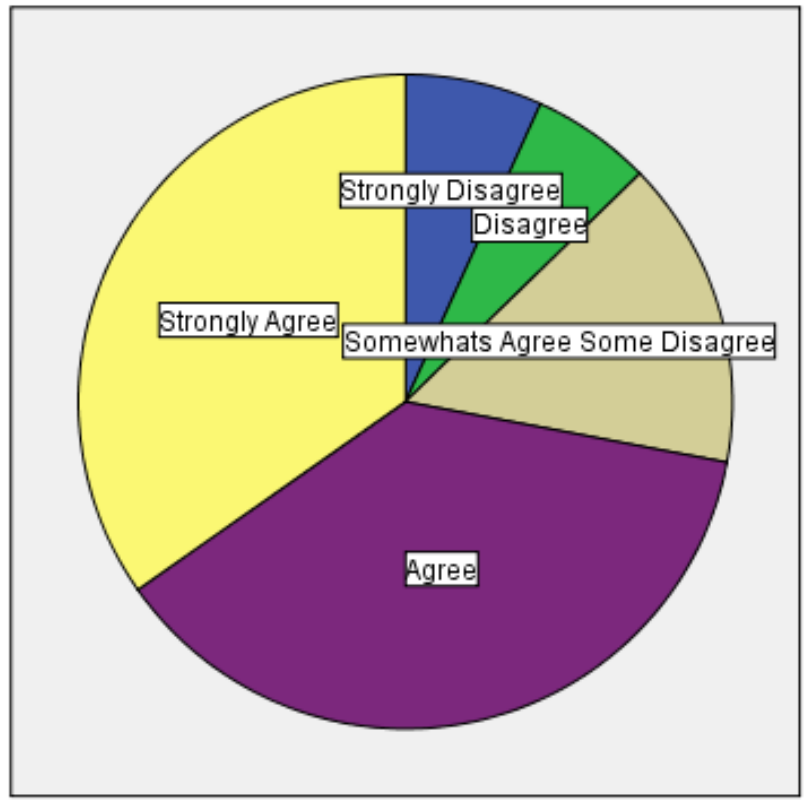

Figure. 6.

The table shows that $6.8 \%$ are strongly disagree with their jobs, $5.9 \%$ are disagree, $15.3 \%$ are somewhat agree and somewhat disagree, $37.3 \%$ are agree and $34.7 \%$ are strongly agre

Table. 6 .

Do your personal problems effect on you moods?

\begin{tabular}{|c|c|c|c|c|c|}
\hline & & $\begin{array}{l}\text { Frequenc } \\
\mathbf{y}\end{array}$ & Percent & $\begin{array}{l}\text { Valid } \\
\text { Percent }\end{array}$ & $\begin{array}{l}\text { Cumulative } \\
\text { Percent }\end{array}$ \\
\hline \multirow{7}{*}{ Valid } & Strongly Disagree & 4 & 3.4 & 3.4 & 3.4 \\
\hline & Disagree & 4 & 3.4 & 3.4 & 6.8 \\
\hline & Somewhats & 13 & 110 & 110 & 178 \\
\hline & Somewhat Disagree & & & & \\
\hline & Agree & 48 & 40.7 & 40.7 & 58.5 \\
\hline & Strongly Agree & 49 & 41.5 & 41.5 & 100.0 \\
\hline & Total & 118 & 100.0 & 100.0 & \\
\hline
\end{tabular}




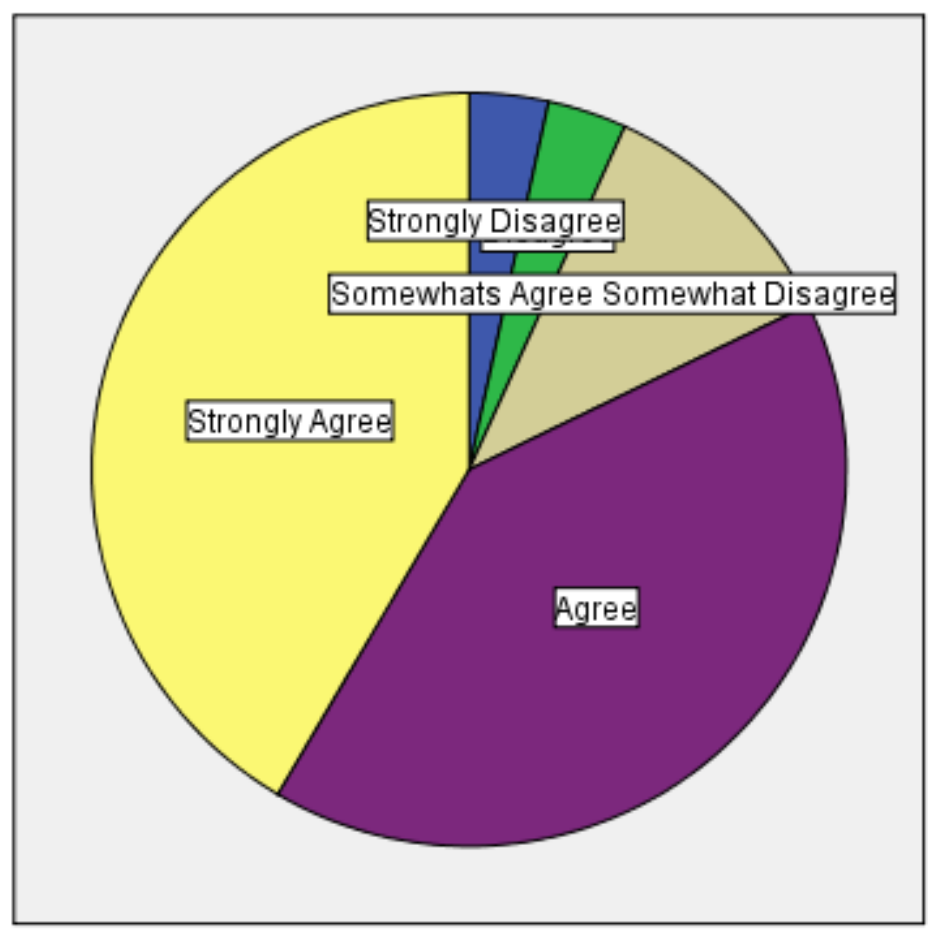

Figure. 7.

The table shows that $3.4 \%$ are strongly disagree with their jobs, $3.4 \%$ are disagree, $11 \%$ are somewhat agree and somewhat disagree, $40.7 \%$ are agree and $41.5 \%$ are strongly agree

Table. 7.

\begin{tabular}{|c|c|c|c|c|c|c|c|}
\hline \\
\hline & & $\begin{array}{l}\text { Does salary } \\
\text { incentive have } \\
\text { positive } \\
\text { impact on } \\
\text { your mood? }\end{array}$ & $\begin{array}{l}\text { Do your } \\
\text { personal } \\
\text { problems } \\
\text { effect on you } \\
\text { moods? }\end{array}$ & $\begin{array}{c}\text { Does } \\
\text { behavior of } \\
\text { family } \\
\text { members } \\
\text { effect on your } \\
\text { work } \\
\text { performance }\end{array}$ & $\begin{array}{l}\text { Does the } \\
\text { behavior of } \\
\text { your } \\
\text { colleague's } \\
\text { effect on your } \\
\text { mood? }\end{array}$ & $\begin{array}{c}\text { Does } \\
\text { behavior of } \\
\text { your superior' } \\
\text { s effect on } \\
\text { your mood for } \\
\text { work } \\
\text { performance" } \\
?\end{array}$ & $\begin{array}{c}\text { Does } \\
\text { behavior of } \\
\text { your } \\
\text { colleague's } \\
\text { effect on your } \\
\text { mood for work } \\
\text { performance? }\end{array}$ \\
\hline \multirow{3}{*}{$\begin{array}{l}\text { Does salary incentive } \\
\text { have positive impact on } \\
\text { your mood? }\end{array}$} & Pearson Correlation & 1 & & & .168 & & \\
\hline & Sig. (2-tailed) & & .001 & .000 & .069 & .000 & .014 \\
\hline & $\mathrm{N}$ & 118 & 118 & 118 & 118 & 118 & 118 \\
\hline \multirow{3}{*}{$\begin{array}{l}\text { Do your personal } \\
\text { problems effect on you } \\
\text { moods? }\end{array}$} & Pearson Correlation & $*$ & 1 & $*$ & ** & & \\
\hline & Sig. (2-tailed) & .001 & & .000 & .000 & .029 & .006 \\
\hline & $\mathrm{N}$ & 118 & 118 & 118 & 118 & 118 & 118 \\
\hline \multirow{3}{*}{$\begin{array}{l}\text { Does behavior of family } \\
\text { members effect on your } \\
\text { work performance }\end{array}$} & Pearson Correlation & & & 1 & .077 & ${ }^{* *}$ & \\
\hline & Sig. (2-tailed) & .000 & .000 & & .404 & .000 & .007 \\
\hline & $\mathrm{N}$ & 118 & 118 & 118 & 118 & 118 & 118 \\
\hline \multirow{3}{*}{$\begin{array}{l}\text { Does the behavior of your } \\
\text { colleague's effect on your } \\
\text { mood? }\end{array}$} & Pearson Correlation & .168 & & .077 & 1 & .026 & \\
\hline & Sig. (2-tailed) & .069 & .000 & .404 & & .784 & .001 \\
\hline & $\mathrm{N}$ & 118 & 118 & 118 & 118 & 118 & 118 \\
\hline \multirow{3}{*}{$\begin{array}{l}\text { Does behavior of your } \\
\text { superior's effect on your } \\
\text { mood for work } \\
\text { performance"? }\end{array}$} & Pearson Correlation & & & & .026 & 1 & \\
\hline & Sig. (2-tailed) & .000 & .029 & .000 & .784 & & .000 \\
\hline & $\mathrm{N}$ & 118 & 118 & 118 & 118 & 118 & 118 \\
\hline \multirow{3}{*}{$\begin{array}{l}\text { Does behavior of your } \\
\text { colleague's effect on your } \\
\text { mood for work } \\
\text { performance? }\end{array}$} & Pearson Correlation & & $*$ & $*$ & ** & $* *$ & 1 \\
\hline & Sig. (2-tailed) & .014 & .006 & .007 & .001 & .000 & \\
\hline & $\mathrm{N}$ & 118 & 118 & 118 & 118 & 118 & 118 \\
\hline
\end{tabular}

Correlation is significant at the 0.01 level (2-tailed)

Correlation is significant at the 0.05 level (2-tailed). 
Table .8.

ANOVA

\begin{tabular}{|c|c|c|c|c|c|c|}
\hline \multicolumn{2}{|c|}{ Model } & Sum of Squares & df & Mean Square & $\mathrm{F}$ & Sig. \\
\hline \multirow{3}{*}{1} & Regression & 24.632 & 2 & 12.316 & 12.452 & $.000^{\mathrm{b}}$ \\
\hline & Residual & 113.741 & 115 & .989 & & \\
\hline & Total & 138.373 & 117 & & & \\
\hline
\end{tabular}

a. Dependent Variable: You feel bad when your boss opinion is different from you?

b. Predictors: (Constant), Does superior praise effect on your mood in positive way? Do you think that your family is satisfied with your professional achievements inside the organization?

63

Coefficients

\begin{tabular}{|l|l|l|l|l|l|}
\hline \multicolumn{2}{|c|}{ Model } & \multicolumn{2}{|l|}{$\begin{array}{l}\text { Unstandardized } \\
\text { Coefficients }\end{array}$} & $\begin{array}{l}\text { Standardized } \\
\text { Coefficients }\end{array}$ & Sig. \\
\cline { 2 - 5 } & $\mathrm{B}$ & Std. Error & Beta & & \\
\hline $\begin{array}{l}\text { (Constant) } \\
\text { Do you think that your } \\
\text { family is satisfied with } \\
\text { your professional } \\
\text { achievements inside the } \\
\text { organization? }\end{array}$ & 1.585 & .270 & & 5.879 & .000 \\
$\begin{array}{l}\text { Does superior praise effect } \\
\text { on your mood in positive } \\
\text { way? }\end{array}$ & .196 & .075 & .304 & 3.309 & .001 \\
\hline
\end{tabular}

\section{Discussion}

The findings show that there is a significant relationship between employee's emotions and organizational behavior. The effect that each variable can have on each other is important. It is a useful information for organizations to increase their work performance and increase productivity. Because finding shows that emotions 
and mood of employees have great effect on their performance which can be cause organizational productivity increase as well as decrease. Organizations and Businessmen always know that employees are their greatest power to earn more profit because more loyal and hard work employees bring more profit through maximize their production. If there is no proper management planning to treat their employees, the business will shut down within few days. Positive Emotions of employees brings:

1. Better facilitate their customers than its competitors.

2. More chances to earn profit

3. Expansion of business

4. Compete the market

5. Making good will

6. Best communication with their customers and build close relationship

\section{Conclusion}

\section{Limitations and future research}

The limitations connected with analysis area unit acknowledged. There ought to be more study on this subject to know the connection between these factors and their impact on one another. This analysis was on little scale. The sample size was little space from that we collected knowledge for this purpose was also little. As this analysis relies on the collected knowledge from some specific areas therefore the results are going to be totally once it's conducted in another different areas and sample size should be also increase.

\section{Disclosure statement}

No potential conflict of interest was reported by the authors.

Contact Information.

Email address: zara@gmail.com 


\section{References and notes:}

Al, f. E. (2000). The influence of emotion on the perfomance.pp. 1-5.

Al, w. (2006). Employees' mood and emotion as imperatives for perceived job. Pp.1-4.

Brief, g. (2006). Employees' mood and emotion as imperatives for perceived job. Pp.1-7.

Et, a. (2017). The effect of emotional intelligence on employee's job performance:.pp. 1-5.

Groth. (2005). Employees' mood and emotion as imperatives for perceived job. Pp.1-6.

Izard. (1991). Positive and negative emotions within the organizational. Pp.1-4.

Naseer:zainab:saeed-ul-hassan. (2011). Impact of emotional intelligence on team performance. Pp.1-4.

Performance, i. O. (2003). Zhou: George. pp.1-3.

Phua:Thomsan. (2012). Employees' mood and emotion as imperatives for perceived job. Pp.1-6. Smith, J. P. (1993). Workplace emotions. Ted Goff. 2001.

Wegge:Dick:Fisher. (2006). Employees' mood and emotion as imperatives for perceived job. pp1-6.

Wong. (2017). The effect of emotional intelligence on employee's job performance:.pp. 1-4. 